\title{
Review \\ CD8 T Cell Vaccines and a Cytomegalovirus-Based Vector Approach
}

\author{
Marko Šustić ${ }^{1}$, Maja Cokarić Brdovčak ${ }^{2}$, Astrid Krmpotić ${ }^{1}$ and Stipan Jonjić ${ }^{2, *}$ \\ 1 Department of Histology and Embryology, Faculty of Medicine, University of Rijeka, 51000 Rijeka, Croatia; \\ marko.sustic@uniri.hr (M.Š.); astrid.krmpotic@medri.uniri.hr (A.K.) \\ 2 Center for Proteomics, Faculty of Medicine, University of Rijeka, 51000 Rijeka, Croatia; \\ maja.cokaric@medri.uniri.hr \\ * Correspondence: stipan.jonjic@medri.uniri.hr
}

Citation: Šustić, M.; Cokarić

Brdovčak, M.; Krmpotić, A.; Jonjić, S. CD8 T Cell Vaccines and a

Cytomegalovirus-Based Vector Approach. Life 2021, 11, 1097. https://doi.org/10.3390/life11101097

Academic Editors: Pero Lučin, Hana Mahmutefendić Lučin and Gordana Blagojević Zagorac

Received: 6 September 2021 Accepted: 15 October 2021 Published: 15 October 2021

Publisher's Note: MDPI stays neutral with regard to jurisdictional claims in published maps and institutional affiliations.

Copyright: (C) 2021 by the authors. Licensee MDPI, Basel, Switzerland. This article is an open access article distributed under the terms and conditions of the Creative Commons Attribution (CC BY) license (https:// creativecommons.org/licenses/by/ $4.0 /)$.

\begin{abstract}
The twentieth century witnessed a huge expansion in the number of vaccines used with great success in combating diseases, especially the ones caused by viral and bacterial pathogens. Despite this, several major public health threats, such as HIV, tuberculosis, malaria, and cancer, still pose an enormous humanitarian and economic burden. As vaccines based on the induction of protective, neutralizing antibodies have not managed to effectively combat these diseases, in recent decades, the focus has increasingly shifted towards the cellular immune response. There is substantial evidence demonstrating CD8 T cells as key players in the protection not only against many viral and bacterial pathogens, but also in the fight against neoplastic cells. Here, we present arguments for CD8 T cells to be considered as promising candidates for vaccine targeting. We discuss the heterogeneity of CD8 T cell populations and their contribution in the protection of the host. We also outline several strategies of using a common human pathogen, cytomegalovirus, as a vaccine vector since accumulated data strongly suggest it represents a promising approach to the development of novel vaccines against both pathogens and tumors.
\end{abstract}

Keywords: CD8 T cells; T-Lymphocytes; vaccines; CMV; cytomegalovirus; vaccine vector

\section{Introduction}

The twentieth century was the golden age of vaccine development with the introduction of national vaccination programs on a massive scale [1]. This policy proved to be extremely effective as the number of new cases of polio, pertussis, measles, and other major infectious diseases plummeted after the introduction of preventive vaccination [2]. Today, the World Health Organization (WHO) estimates that preventive vaccination annually saves millions of lives [3,4]. Not only does vaccination save millions of people from premature death and unnecessary suffering, it is also hugely beneficial in economic terms. Studies have shown that the net benefit of vaccination in a developed country such as the Unites States can be up to $\$ 68$ billion [5]. In low- and middle- income countries, where infectious diseases are still the leading cause of child morbidity and mortality [6], an investment of $\$ 34$ billion in vaccination is estimated to result in savings of up to $\$ 586$ billion in the direct cost of illness alone [7].

Although the benefit of vaccination has been known since the cowpox experiments of Edward Jenner [8], the biological mechanisms conferring an increased protection against infectious agents came to light only with the advent of modern immunology. Since then, it has become apparent that the majority of currently administered vaccines mediate their protection via the generation of protective, neutralizing antibodies [2,9]. Unfortunately, vaccines inducing a humoral immune response have not managed to solve the problem of numerous infectious diseases that still pose a major public health threat on a global scale, since the annual number of new cases for HIV, malaria, and tuberculosis are estimated to be 1.5 million, 230 million, and 10 million, respectively [10-12]. Influenza causes periodic 
annual epidemics with millions of cases. Moreover, Hanta viruses, Ebola, novel Flaviviruses such as Chikungunya and Zika, not to mention coronaviruses, such as Sars-CoV-2 which caused the COVID-19 pandemic, all present major threats to public health.

The bulk of effort in vaccine development has been received by humoral based immunization approaches [13]. However, as the intricacies of CD8 T cell biology became better known, a benefit of utilizing their cytotoxic properties and breadth of their epitope targeting for developing successful vaccines became apparent [14]. There is substantial evidence implicating CD8 T cells as the major determinant of protection not only against numerous viral and bacterial pathogens, but also in the fight against neoplastic cells [15-17]. Therefore, in this review we discuss the current evidence implicating CD8 T cells as important targets of vaccination strategies against pathogens and tumors. We also discuss the heterogeneity of memory CD8 T cell populations and their importance in the protection of the host. Finally, we describe several different attempts to use a common human pathogen, cytomegalovirus (CMV), as a vaccine vector with excellent properties for the induction of a potent and effective CD8 T cell response against vectored antigens. Although adequate CD8 $\mathrm{T}$ cell response cannot be generated without CD4 T cell help and this has to be taken into account when designing effective vaccine strategies [18], in this review, we focus exclusively on CD8 T cell biology.

\section{T Cell vs. B Cell Vaccines}

Do we really need CD8 T cell-based vaccines? To start answering this question, we first have to look at the evidence showing a memory CD8 T cell mediated control of infectious pathogens. Activated antigen specific CD8 T cells recognize microbial derived epitopes in complex with MHC-I molecules on the surface of infected cells. Upon recognition, CD8 T cells produce cytokines such as IFN $\gamma$ and TNF $\alpha$ that induce widespread anti-microbial state, or, more locally, these CD8 T cells secrete cytotoxic molecules such as perforins and granzymes that initiate an apoptosis of the targeted cell [19,20]. Countless studies demonstrated CD8 T cell mediated pathogen clearance in animal models of infections. Memory CD8 T cells protect mice against several viral infections, including lymphocytic choriomeningitis virus (LCMV) [21], respiratory-syncytial virus (RSV) [22], and vaccinia virus (VV) [23]. In a mouse model of influenza infection, the loss of CD8 T cells resulted in a delayed viral clearance and host recovery [24,25]. Chronic viral infections with rapidly mutating viruses, such as HIV, pose a greater challenge for CD8 T cells. Despite that, rhesus macaques control simian immunodeficiency virus (SIV) spread via CD8 lymphocytes during acute infection, but also prevent SIV viremia surge during chronic infection as the depletion of this population has led to a rapid and substantial increase in viremia [26]. The importance of memory $\mathrm{T}$ cells was also implicated in parasitic infections. In a study by Schmidt et al., the authors induced large numbers of CD8 T cells specific for an immunodominant Plasmodium berghei epitope via heterologous prime-boost vaccination with antigen coated DCs and attenuated Listeria monocytogenes expressing the same epitope and managed to induce immunological protection against malaria challenge for at least 19 months [27].

Although most of the data accumulated so far on the relevance of the CD8 T cell response were obtained on animal models, research conducted on human immune response in recent decades essentially validated most of these observations. For instance, virus-specific memory CD8 T cells can be detected in humans even decades after acute viral infections or immunization with live attenuated vaccines $[28,29]$. Furthermore, a study by Akondy et al. tracked CD8 $\mathrm{T}$ cell response after vaccination with yellow fever virus (YFV) vaccine and showed that the memory pool of CD8 T cells is maintained by quiescent cells that divide only sporadically, with a doubling time of less than once a year. These CD8 T cells were identified even a decade after vaccination and possessed an epigenetic profile that indicated their potential for rapid response upon pathogen re-encounter [30]. The results obtained from several clinical studies of human influenza A (IAV) infection also corroborate the findings from the mouse model. An analysis of 342 adult individuals in a 
household control cohort study demonstrated an inverse correlation of pre-existing CD8 T cells directed against conserved influenza A epitopes and clinical symptoms associated with IAV infection [31]. Moreover, it has been shown that CD8 T cell numbers correlated with recovery from H7N9 influenza infection [32]. When it comes to HIV infection, the first indicators of CD8 T cell importance in suppressing viral replication came from GWAS studies. These studies identified $H L A-B$ and $H L A-C$ loci as almost entirely determining variations of HIV control in infected individuals [33]. A substantial enrichment in the frequency of $H L A-B^{*} 5701$ allele has been seen in elite HIV controllers compared to chronic progressors [34]. Beside genetic associations, studies examining cell functionality demonstrated that CD8 T cells isolated from controllers consistently showed a higher proliferative and cytolytic potential than cells isolated from patients with progressive infection $[35,36]$. Finally, in silico modeling of HIV mutational landscape showed that regions of structural Gag protein targeted by CD8 T cells of elite controllers have lower mutational tolerance than those targeted by progressors [37-39]. This implies that targeting conserved, essential sequences in HIV proteins is highly beneficial in protecting the host against the onset of AIDS. CD8 T cells are also strongly linked to protective immunity against Listeria monocytogenes [40], Ebola virus [41-43], and HCV [44,45], and to a lesser extent, against malaria [46], tuberculosis [47], and the currently raging Sars-CoV-2 virus [48].

Some peculiarities of CD8 T cell immunobiology, not present in humoral immune response, can be exploited to generate a vaccine against pathogens where $\mathrm{B}$ cell-based approaches have failed so far (Table 1). Neutralizing antibodies typically recognize heavily glycosylated structural proteins expressed on the outer surface of virions $[23,49]$. As these are highly variable proteins, humoral vaccines targeting them make the emergence of serological variants capable of escaping immune control very likely, especially in RNA viruses such as HIV or influenza. Conversely, in addition to structural proteins, CD8 T cells recognize epitopes derived from more conserved non-structural and internal proteins, making them better equipped to tackle mutated strains [50-52]. Moreover, CD8 T cells recognize a much broader repertoire of antigens than antibodies. In one of the earlier studies, an analysis of Immune Epitope Database and Analysis Resource (IEDB) revealed as much as 246 distinct epitopes restricted by MHC class I, and only 9 antibody epitopes in VV infection [23], with the majority of CD8 epitopes being derived from proteins expressed with early kinetics not found in the virions [53,54]. There is another intrinsic biological limitation imposed on humoral based vaccines, elegantly elaborated in recent publication by Stamper and Wilson [55]. Activation-induced cytidine deaminase (AID) generates somatic hypermutation during the germinal center reaction by deaminating cytosines. This enzyme does not target all cytosines equally, but rather has a propensity for deamination depending on the context within which these cytosines are located [56]. This means that immunoglobulin genes that have a higher percentage of deamination prone cytosines will mutate more frequently and have a higher likelihood of generating a favorable mutation which will be selected for during affinity maturation. As a result, the number of cytosines and the likelihood of favorable mutations will decrease as the germinal center reaction progresses. This has a very clear evolutionary benefit for the host as proven affinity-matured antibodies will be protected from detrimental mutations. However, it also limits the potential of memory B cells for re-diversification upon secondary antigen encounter. In this regard, further impediments for antibody diversification were identified in recent work by Mesin et al. [57]. They discovered that recall germinal centers are primarily composed of recruited naive clones and that memory B cells re-enter germinal center reaction only sporadically and hence rarely re-diversify. Altogether, these findings imply that antibody response upon antigen re-encounter becomes increasingly narrow and specialized, thus unable to cope with mutated variants. This is especially troublesome in infections with pathogens prone to mutations, such as HIV or influenza. On the other hand, memory CD8 T cell populations seem to have come up with a solution to tackle the evolutionary changes of pathogens. By enrolling cells with both high and low antigen affinities into memory CD8 T populations, high clonal diversity can be generated and 
maintained during extended periods of time, sufficiently broad to mount an effective and protective response against mutated pathogens [58-60]. Finally, it is worth stating that although intrinsic biological reasons exist for preferring one approach over the other, " $\mathrm{T}$ cell vs B cell" debate represents a case of false dichotomy as a perfect vaccine elicits both protective neutralizing antibodies and broad and effective $\mathrm{T}$ cell response.

Table 1. Differences in antigen targeting between CD8 T cells and B cells.

\begin{tabular}{|c|c|c|}
\hline & CD8 T Cells & B Cells \\
\hline Targeted antigens & $\begin{array}{l}\text { Structural and non-structural } \\
\text { proteins }[50-52]\end{array}$ & Surface proteins $[23,49]$ \\
\hline Spectrum of antigens & Broad $[23,53,54]$ & Narrow [23] \\
\hline $\begin{array}{l}\text { Response upon antigen } \\
\text { re-encounter }\end{array}$ & High clonal diversity [58-60] & Focused and specialized [57] \\
\hline
\end{tabular}

\section{Memory CD8 T Cell Subsets: The Division of Labor}

Long-term T cell-mediated protection depends upon the formation of a pool of memory cells ready to respond to future pathogen encounter. After pathogen clearance, the majority of effector CD8 T cells undergo apoptosis and only a small subset of memory cells persists long term in the mammalian organism (Figure 1). Natural selection has sculpted this population with a single goal in mind: to rapidly generate superior immunological responses upon re-encounter with pathogenic microorganism. What does this superior immunological response entail? Firstly, increased numbers of antigen specific cells capable of rapid and extensive proliferation upon antigen reencounter. Secondly, cells capable of immediate cytotoxicity and rapid cytokine production and finally, adequate anatomical distribution of effector cells in the tissue in which the pathogen re-encounter is most likely to occur. It seems that evolutionary processes have generated functional and anatomical heterogeneity in the CD8 $\mathrm{T}$ cell memory compartment roughly corresponding to these needs. The two traditional circulatory populations are central (Tcm) and effector memory (Tem) cells. Central memory cells express CD62L and CCR7 molecules, enabling their entry into secondary lymphoid organs, where the antigens draining from the tissue, if recognized as cognate, induce their rapid and extensive proliferation [61-63]. In contrast, initial studies classified Tem cells as CCR7- ${ }^{-}$D62 $\mathrm{L}^{-}$and this pattern of chemokine and integrin receptor expression preferentially situates them in the bloodstream and non-lymphoid tissues. These cells show increased cytotoxicity and a rapid development of effector functions $[61,64,65]$. Transcription factors involved in the differentiation and maintenance of Tcm cells are Eomes [66], TCF1 [63], Id3 [67], Bcl6 [68], and Stat3 [69], while transcription factors linked to the formation of Tem cells include T-bet [70], Blimp1 [71], Id2 [72], and Stat4 [73]. More recent studies have identified several subpopulations within Tem compartment, including a $\mathrm{KLRG}^{+}$, terminally differentiated population that likely originates from effector cells surviving the contraction phase of acute CD8 T cell response [64,74]. Further problems for this simple model of functional distinction emerged when Wherry et al. reported that there is no substantial difference in cytokine producing capabilities (with notable exception in IL-2 production) nor cytotoxicity between Tcm and Tem in acute LCMV infection [62]. On the other hand, several studies obtained different results where Tem cells showed higher cytotoxic capability and an increased protection against bacterial infection [75] and VV [76]. Interestingly, Tcm population was far superior against tumor challenge than Tem cells, due to its lymphoid tissue homing properties which entailed a rapid contact with the tumor antigen and subsequent proliferation and differentiation into effector cells [77]. The fact that different cellular populations confer an increased protection in different pathological conditions needs to be taken in consideration when constructing a CD8 T cell-based vaccine. It implies that "one size fits all" approach is most likely to fail and that CD8 vaccines need to be tailored to a specific pathogen or tumor. This is clearly demonstrated by the fact that in the study by Miller et al., the same population (KLRG1 $1^{+}$terminal-Tem) conferred 
excellent protection against Listeria monocytogenes but failed to even minimally affect the growth of murine melanoma [74].

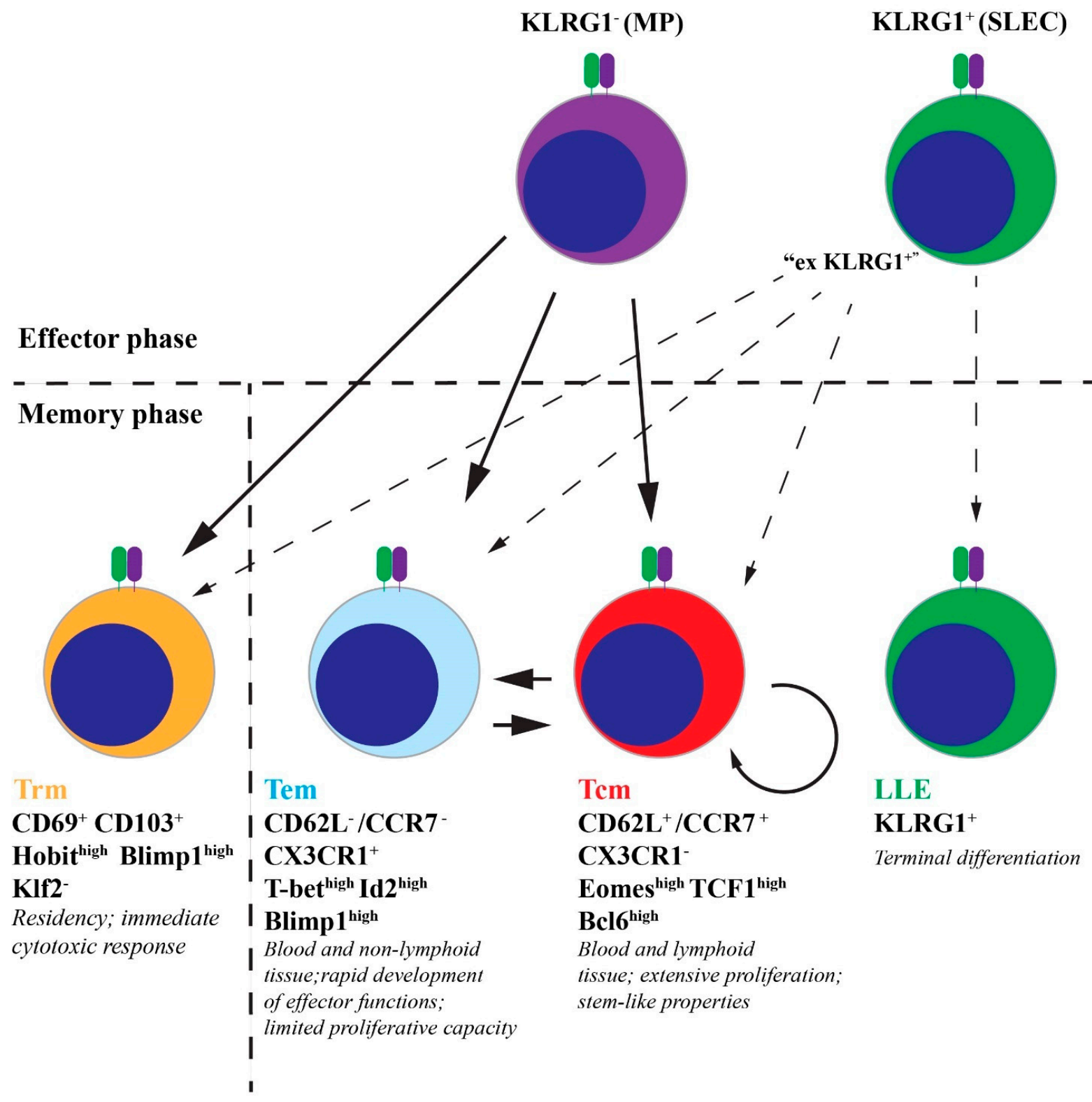

Figure 1. Differentiation and heterogeneity of memory CD8 T cells. Following the resolution of acute infection, the majority of effector CD8 T cells die off through the process of apoptosis. KLRG1- cells preferentially survive and differentiate into all of memory CD8 T cell linages. However, some of the KLRG1 ${ }^{+}$cells lose the expression of KLRG1 ("ex-KLRG1 ") and also seed the memory compartment. A small proportion of terminally differentiated KLRG1 $1^{+}$cells survive as "long-lived effector" (LLE) cells. Memory compartment consists of resident memory (Trm), effector memory (Tem) and central memory (Tcm) cells. MP (memory precursor); SLEC (short-lived effector cells).

The need for an adequate distribution of memory cells capable of immediate effector response in the peripheral tissue is supplied by tissue resident memory T cells (Trm). These cells remain locked in the tissue via the expression of CD69 and CD103 proteins. CD69 antagonizes the function of S1PR1 (sphingosine-1-phosphate receptor), thereby inhibiting the egress of resident cells from the tissue [78]. An important transcription factor for the expression of S1PR1 is KLF2 and this protein is inhibited in Trm cells by the Hobit transcription factor [79]. Other transcription factors that positively influence Trm formation are Runx3 [80], Notch [81], and Blimp1 [79,82]. Although it was initially thought that the 
defining characteristics of this population is the absence of migration, a recent study by Wijeyesinghe et al. revealed some degree of migration as these cells did seed the circulatory pool of Tem cells [83]. Regardless of their migration properties, Trm cells are poised for immediate effector functions producing high levels of Granzyme B and IFN- $\gamma$ upon antigen encounter [84-87] and this population substantially contributed to the protection against a wide variety of infectious pathogens, such as herpes simplex virus [88], VV infection of the female reproductive tract [89], chlamydia [90], genital herpes [91], and others [92]. In a model of cutaneous skin infection with VV, the presence of Trm cells led to no less than a $10^{4}$ fold reduction in the viral load [93], demonstrating just how effective Trm cells can be in the protection of the host. Tissue resident memory cells were also shown to play an important role in the mouse melanoma model $[94,95]$. More importantly, a higher frequency of tissue resident cells was associated with increased survival in breast [96], lung [97], and ovarian cancers [98] (also reviewed in [99]). Several groups developed vaccination strategies that were able to induce large numbers of Trm cells poised to protect the tissue form infections and neoplastic growth. The immunization of mice via skin scarification with recombinant VV expressing OVA protein led to an enhanced protection against B16-OVA melanoma model [100] and against local vaccinia challenge [101]. Interestingly, both mucosal resident cells and circulating Tcm cells were needed to generate an adequate protective response against lethal respiratory VV challenge [101]. Tartour's group developed a different approach, using non-replicative vaccine based on a B subunit of Shiga-toxin fused to tumor antigens. After mucosal immunization, but not intramuscular route, they induced CD49a ${ }^{+}$ and $\mathrm{CD}_{103^{+}}$Trm cells which inhibited the growth of orthotopic head and neck tumor and lung cancers $[102,103]$. Another approach to generate Trm cells was developed by Iwasaki's group, called "prime and pull" method [91]. Instead of local antigen delivery, this method uses non-local immunization followed by local chemokine application to "pull" $\mathrm{T}$ cells to specific peripheral tissue. The authors immunized mice subcutaneously with attenuated HSV-2 strain and applied CXCL9 and CXCL10 chemokines topically to the vaginal cavity. $\mathrm{T}$ cells were recruited to the tissue with these chemokines via CXCR3 and established longterm residency which prevented the development of clinical diseases upon intravaginal challenge with a lethal HSV-2 virus. By comparison, only around $40 \%$ of animals immunized subcutaneously without the "pulling" of T cells to vaginal mucosa survived the challenge. The "prime and pull" strategy also led to substantially lower latent viral load in dorsal root ganglia, demonstrating the important role of resident cells in containing infection and preventing viral dissemination (also reviewed extensively in [104]).

\section{Cytomegalovirus Based Vaccine Vectors}

In the last two decades, it became evident that latently persistent viruses, such as CMV, generate a quite peculiar pattern of epitope specific $\mathrm{T}$ cell response, exemplified by the large numbers of cells exhibiting Tem phenotype with increased effector functions and without the signs of $\mathrm{T}$ cell exhaustion. These cells are maintained over the lifetime of the host, and importantly, the frequency of CD8 T cells specific for certain viral epitopes increases during the latency of the virus in a process known as memory inflation (reviewed in [105] see also $[106,107])$. This phenomenon was exploited by several groups in order to build a recombinant CMV based vaccine expressing exogenous antigens that would induce high numbers of effector cells, capable of a rapid control and elimination of infectious pathogens (Figure 2 and Table 2). Remarkable results were obtained by the groups of Luis Picker and Klaus Früh using this strategy in the protection against SIV, a virus closely related to HIV. They generated recombinant rhesus macaque CMV vectors (RhCMV) expressing several different SIV antigens and immunized rhesus macaques with a mixture of these vectors. In their initial study, the authors showed that RhCMV vectors expressing SIV antigens persistently infected monkeys, regardless of their pre-existing latent RhCMV infection. They were able to induce potent CD4 and CD8 T cell response, enriched in cells expressing Tem phenotype and animals vaccinated with these vectors showed increased resistance to repeated intrarectal SIV infection [108]. Next, they expanded on these findings and com- 
pared this approach to a vaccination protocol consisting of DNA vaccine and adenoviral vector that predominantly generates cells with Tcm phenotype. One year after vaccination, they intrarectally challenged macaques with a highly pathogenic SIV strain. Although the magnitude of CD8 T cells induced with different vaccination strategies were comparable at the end of vaccine phase, 13 out of 24 macaques immunized with RhCMV vectors rapidly controlled SIV spread while all of the DNA/adenovector vaccinated monkeys showed progressive infection. Protection correlated directly with Tem frequency, and interestingly, seemed to show an "all or nothing" pattern as macaques vaccinated with RhCMV vectors either completely controlled viral spread or exhibited the same level of viremia as unvaccinated controls [109]. It was later discovered that SIV is not immediately controlled at the entry site of vaccinated animals, but rather establishes infection in draining lymph nodes, bone-marrow, spleen, and liver. However, using an ultra-sensitive nested PCR 69-180 weeks after viral challenge, the authors failed to detect viral genome in these tissues in RhCMV vaccinated monkeys and when they adoptively transferred hematolymphoid cells from vaccinated animals to naïve hosts, no signs of infection were observed in the recipients [110]. Together, these results strongly indicated that despite breaking through the mucosal barrier and establishing productive infection in the tissues, SIV was controlled and completely cleared via Tem CD8 cells from the majority of vaccinated monkeys. In their subsequent studies [111,112], the authors analyzed epitope distribution and restriction patterns of CD8 T cells induced with RhCMV vectors, making several surprising discoveries. Firstly, CD8 T cells induced with RhCMV vectors had much broader epitope distribution than natural controllers or monkeys immunized with different vaccination modalities, recognizing on average 40 epitopes (average in other groups was 10-18). Secondly, all of the epitopes in RhCMV vacinated group where MHC-II or MHC-E restricted, without any canonical MHC-I epitopes. The loss of several genes in RhCMV viral strain used as a backbone for the vectors was responsible for this phenomenon and the restitution of these genes led to the loss of this heterodox restriction pattern [112]. Finally, they also discovered the crucial role of VL9 peptide embedded within Rh67 viral protein in MHC-E restricted CD8 T cell priming, as the loss of this gene resulted in failure of RhCMV vectors in protection against SIV challenge [113]. Hansen et al. also developed RhCMV vectors carrying Mycobacterium tuberculosis antigens. Immunization with these vectors resulted in significantly greater protection against pulmonary tuberculosis compared to unvaccinated animals, but also as compared to BCG immunized monkeys [114]. Finally, the same strategy was tried against malaria, but with modest success [115]. Although this strategy is a very promising approach to HIV vaccine development, this research might have a much broader and important implication for T cell-based vaccines. For some MHC-E epitopes, all of the vaccinated monkeys developed a CD8 T cell response, regardless of MHC-I haplotype. Due to the very limited MHC-E polymorphism in human population [116,117], it is quite plausible to presume that a vaccine targeting MHC-E restricted CD8 T cells would induce an immune response in all vaccinated individuals, thereby bypassing the perennial obstacle of MHC-I polymorphism in generating a successful, widely applicable CD8 T cell vaccine. After twenty years of development and preclinical studies, this approach is finally being tested in a Phase 1a clinical trial, in which CMV seropositive healthy individuals are being vaccinated with an HCMV expressing HIV antigens, which will be followed by Phase 2 and 3 trials in which the efficacy of this strategy will be determined [118].

A different strategy was investigated by the Cicin-Sain group. Instead of targeting Tem cells, the authors focused on the induction of protective Trm cells within the lungs. They generated an MCMV vector expressing an IAV epitope derived from hemagglutinin and intra-nasal immunization with this vector conferred substantial protection against IAV challenge [119]. A CMV vector was also utilized to develop a vaccination strategy against another major public health threat, Ebola. Ebola predominantly spreads to human populations from the infected carcasses of great apes, and Jarvis et al. argued that using a vector carrying Ebola antigens that can rapidly spread through targeted monkey populations can prevent Ebola outbreaks from skipping to humans. As a "proof of con- 


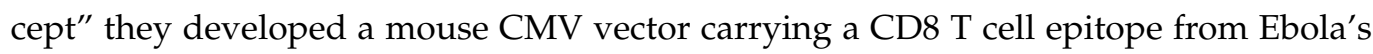
nucleoprotein (MCMV/ZEBOV-NP $\mathrm{CTL}_{\mathrm{TL}}$ ) and this vector was able to confer excellent protection of mice against lethal Ebola challenge [120]. After this initial study, the authors also developed an RhCMV expressing Ebola virus glycoprotein and successfully vaccinated rhesus macaques with this vector, conferring to vaccinated animals substantially greater survival against lethal Ebola challenge compared to their unvaccinated counterparts [121]. Whether immunity following animal-to-animal spread will be sufficiently potent to protect the animals against Ebola induced disease still needs to be established. Finally, Nejad et al. constructed MCMV vectors expressing human papilloma virus (HPV) antigens, E6 and E7. By experimenting with different dosages and inoculation routes, they determined the threshold of tumor specific CD8 T cell response necessary for a complete protection against a tumor cell line harboring HPV antigens. Importantly, the authors demonstrated that high levels of pre-existing immunity to MCMV hamper subsequent immune response to an MCMV vector carrying tumor epitopes which leads to the loss of protection against subcutaneous tumor challenge [122]. Additionally, CMV vectors targeting melanoma antigens such as gp100 and TRP2 [123,124] and human prostate specific antigens (PSA) [125] were also developed.

A) ANTIGEN PRESENTATION AFTER VACCINATION

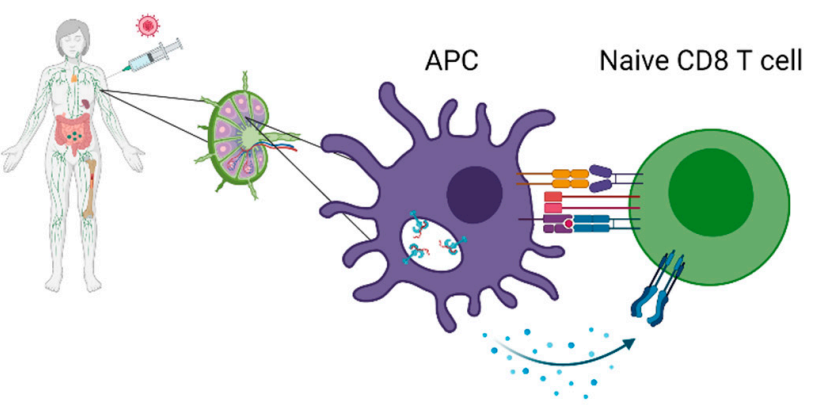

C) T CELL RESPONSE AFTER VACCINATION AND PATHOGEN ENCOUNTER

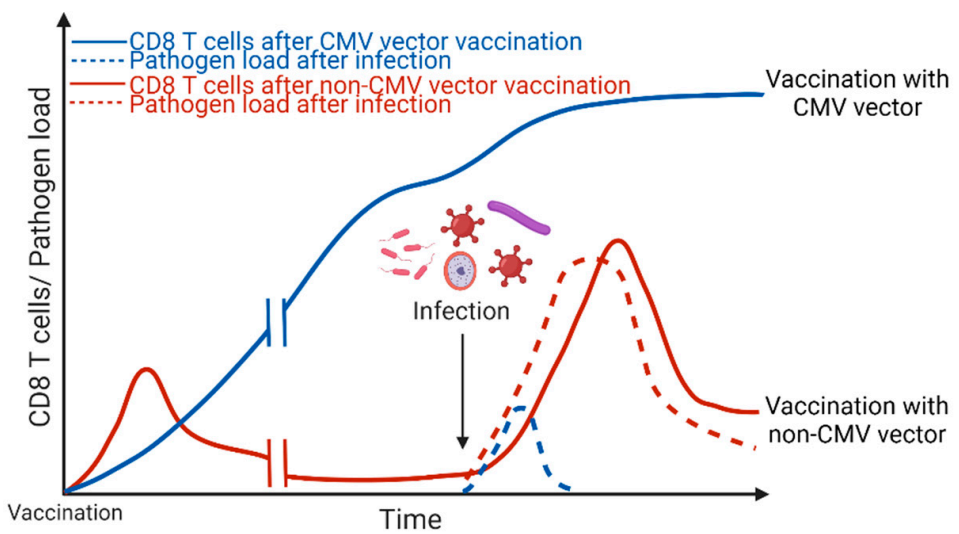

B) ANTIGEN PRESENTATION DURING CMV LATENCY AND BOOSTING OF CD8 T CELL RESPONSE

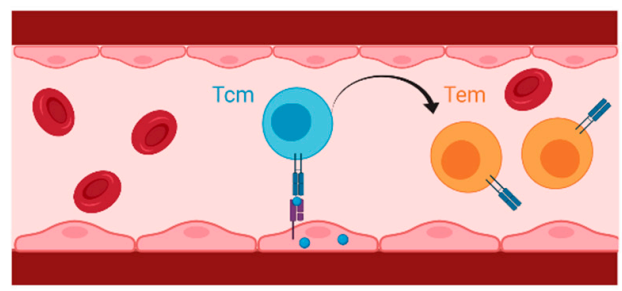

BLOOD VESSEL

D) KILLING OF INFECTED CELLS

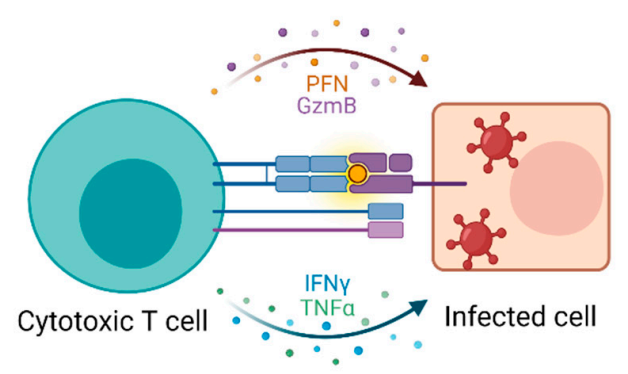

Figure 2. The model of CD8 T cell response induced with a CMV vector. (A) Following vaccination, dendritic cells in the draining lymph nodes present the vectored antigens to naïve CD8 T cells, which leads to proliferation and differentiation of CD8 T cells into multiple effector and memory lineages. (B) During CMV latency, sporadic viral reactivations boost CD8 $\mathrm{T}$ cell response, with accumulation of Tem cells, capable of immediate cytotoxic activity [105]. (C) CD8 T cell response upon immunization with a CMV vector compared to a vaccine that induces a "canonical" CD8 T cell response. CMV maintains high frequency of memory CD8 T cells specific for vectored antigens which allows for rapid pathogen control upon infection. (D) Upon recognition of pathogen derived antigens on the surface of infected cells, CD8 T cells secret perforins (PFN) which form pores in the cellular membrane of the targeted cell, allowing granzymes (Gzm) to enter the cytosol and initiate apoptosis. APC (antigen presenting cell); Tem (T effector memory); Tcm (T central memory). This figure was created with Biorender. 
In vaccine development, considerations of safety are as important as those of immunogenicity. Our group developed an attenuated but highly immunogenic vaccine vector based on mouse cytomegalovirus equipped with a ligand for an activating NKG2D receptor. The rationale behind this approach was the activating role of NKG2D on NK cells, which would provide a quick control of a vector carrying an NKG2D ligand, but also a costimulatory role of this receptor on CD8 T cells [126]. We inserted an NKG2D ligand RAE- $1 \gamma$ in place of its viral inhibitor m152 (RAE- $1 \gamma \mathrm{MCMV}$ ) and this virus proved to be highly attenuated compared to wild-type virus, but despite this, induced an equal CD8 T cell response to inflationary $\mathrm{m} 164$ and pp89 epitopes and comparable amounts of circulating antibodies against MCMV. Neutralizing antibodies generated with RAE- $1 \gamma M C M V$ were transferred through the placenta to fetuses of pregnant female mice and were able to protect newborns against pulmonary and brain MCMV infection. RAE- $1 \gamma \mathrm{MCMV}$ virus was attenuated in an NKG2D dependent manner, as blockade of NKG2D using monoclonal antibodies led to a loss of attenuation. Additionally, this virus remains stable in the host over extended periods of time without the loss of the RAE- $1 \gamma$ gene [127]. In our further research, we inserted a foreign epitope, Listeria monocytogenes derived LLO epitope or ovalbumin derived SIINFEKL, into the RAE- $1 \gamma \mathrm{MCMV}$ backbone. Irrespective of the attenuation, RAE- $1 \gamma \mathrm{MCMV}$ generated a superior CD8 T cell response to inserted foreign epitopes and conferred a superior protection against Listeria monocytogenes infection. Surprisingly, this phenomenon was not lost in $\mathrm{Klrk1}^{--}$animals, suggesting that either RAE- $1 \gamma$ has an unknown interaction partner or that superior CD8 response is independent of ectopic RAE- $1 \gamma$ expression [128]. We also tested the protective capacity of RAE- $1 \gamma$ expressing vector against subcutaneous tumor challenge and demonstrated its excellent anti-tumor capabilities [129]. Recently, we performed a detailed characterization of memory CD8 T cells induced with RAE- $1 \gamma \mathrm{MCMV}$ vector expressing the SIINFEKL epitope. A transcriptomic analysis of RAE- $1 \gamma \mathrm{MCMV}$ primed CD8 T cells showed a terminally differentiated, effector like phenotype with higher expression of effector genes such as $C x 3 C r 1$ and $G z m$ B, while wild-type (MCMV-SIINFEKL) primed cells had a higher expression of prototypical Tcm genes, Sell and Ccr7. Interestingly, cells positive for TCF1 transcription factor (crucially associated with Tcm phenotype, stemness and long-term persistence [130]) were more numerous in MCMV-SIINFEKL primed CD8 $\mathrm{T}$ cells, but the difference was observed only at memory time-points, beginning around day 30 . These phenotypical differences also entailed functional distinctions, but upon adoptive transfer of equal numbers of CD8 T cells into mice harboring subcutaneous tumors, cells primed with both vectors showed similar tumor-rejecting capabilities [131]. Finally, we developed an MCMV viral vector containing another NKG2D ligand, MULT-1. MULT-1 has the highest affinity for NKG2D and demonstrated even higher attenuation than RAE- $1 \gamma \mathrm{MCMV}$. Cellular immune response for inserted foreign epitope was somewhat inferior to RAE- $1 \gamma$ expressing vector, but the humoral response was comparable and provided equal protection to newborns of vaccinated mothers against congenital MCMV infection [132]. The translational potential of CMV vector expressing an NKG2D ligand was confirmed by generating a human CMV (HCMV) armed with a human homologue of RAE- $1 \gamma$, ULBP2 [133]. Here, the TB40 strain which lacks several immunoevasive genes such as US2, US3, and US6 whose function is to interfere with MHC-I expression on the surface of infected cells, was used as a vector backbone. ULBP2-HCMV was attenuated via NK cells and NKG2D receptor but showed comparable humoral and T cell response to viral antigens in humanized mice models. These results demonstrate the feasibility of HCMV based vector vaccines, but several points need to be highlighted. Since HCMV shows high prevalence in the human population, a necessary precondition for a wide use of CMV based vectors is a capability of these vectors to superinfect HCMV positive hosts. Hansen et al. showed that precisely the RhCMV homologs of US2, US3 and US6 are necessary for superinfection of RhCMV positive rhesus macaques [134]. If these results obtained from non-human primates can be extrapolated to humans, the deficiency of viral immunoevasins in ULBP2-HCMV needs to be further addressed. 
Table 2. Cytomegalovirus (CMV)-based vaccine vectors.

\begin{tabular}{|c|c|c|c|c|}
\hline Vaccine Vector & Inserted Antigen & Disease (Challenge) Model & Immune Response & Selected References \\
\hline $\mathrm{RhCMV} / \mathrm{SIV}$ & Env, gag, rev-tat-nef (fusion protein) & Highly pathogenic SIV strain intra-rectal challenge & \multirow{4}{*}{$\mathrm{CD} 8 \mathrm{~T}_{\mathrm{EM}}$ cell response } & [108-113] \\
\hline $\mathrm{RhCMV} / \mathrm{TB}$ & $\begin{array}{c}\text { Ag85A, Ag85B, Rv3407, Rv1733, Rv262, Rpf A, } \\
\text { Rpf C, Rpf D, ESAT-6 }\end{array}$ & $\begin{array}{l}\text { Mycobacterium tuberculosis Erdman strain } \\
\text { intrabronchial challenge }\end{array}$ & & [114] \\
\hline $\mathrm{RhCMV} / \mathrm{Pk}$ & CSP, AMA1, SSP2/TRAP, MSP1c & Plasmodium knowlesi sporozoites challenge & & [115] \\
\hline MCMV/ZEBOV-NP $\mathrm{CTL}$ & $\begin{array}{l}\text { CD8 T cell epitope from the nucleoprotein (NP) } \\
\text { of Zaire ebolavirus }\end{array}$ & Mouse adapted ZEBOV challenge & & [120] \\
\hline $\mathrm{MCMV}^{\mathrm{IVL}}$ & MHC-I restricted IVL $\mathrm{L}_{533-541}$ epitope & Lethal IAV PRM8 variant challenge & $\mathrm{CD} 8 \mathrm{~T}_{\mathrm{RM}}$ cell response & [119] \\
\hline $\mathrm{MCMV} / \mathrm{PSA}_{65-73}$ & MHC-I restricted PSA $_{65-73}$ epitope & $\begin{array}{l}\text { Prostate cancer model } \\
\text { (TRAMP-PSA tumor cells) }\end{array}$ & $\mathrm{PSA}_{65-73}$ inflationary CD8 $\mathrm{T}$ cell response & [125] \\
\hline RAE-1 $\gamma$ MCMVList & $\begin{array}{l}\text { MHC-I restricted epitope of Lysteria } \\
\text { monocytogenes listeriolysin } \mathrm{O}_{91-99} \text { (LLO) }\end{array}$ & $\begin{array}{l}\text { Hemolytic EGD strain (serovar1/2a) of Lysteria } \\
\text { monocytogenes challenge }\end{array}$ & \multirow[t]{2}{*}{ Protective CD8 T cells } & [128] \\
\hline RAE-1 $\gamma$ MCMV-SIINFEKL & MHC-I restricted peptide SIINFEKL & B16OVA (melanoma) and EG7 (thymoma) model & & {$[129,131]$} \\
\hline MCMV-M79-FKBP-E7 & HPV16 E7 $49-57$ epitope & $\begin{array}{l}\text { Subcutaneous administration of } \\
\text { TC-1 cells transformed with HPV16 E6/E7 and } \\
\text { c-H-ras oncogenes }\end{array}$ & $\begin{array}{l}\text { Tumor-specific protective } \\
\text { CD8 T cells }\end{array}$ & [122] \\
\hline MCMV-gp100 $127 \mathrm{P}$ & gp100 $25-33$ peptide $\left(\mathrm{gp} 100^{\mathrm{S} 27 \mathrm{P}}\right)$ & Subcutaneous B16F0 melanoma model & Tumor-infiltrating antigen-specific CD8 T cells & [123] \\
\hline MCMV-TRP2 & $\begin{array}{l}\text { Mouse tyrosinase-related protein } 2 \\
\text { melanoma antigen }\end{array}$ & B16 melanoma challenge & IgG antibody-mediated tumor protection & [124] \\
\hline
\end{tabular}




\section{Conclusions}

The heightened interest in generating CD8 T cell-based vaccines in recent years has coincided with an expansion of our understanding of basic molecular features in CD8 T cell immunobiology. The advances of single cell-sequencing technology and mass-cytometry have revealed substantially greater heterogeneity in the CD8 memory compartment than previously thought and using these novel technologies in identifying a population best suited to tackle a given pathological condition can have immense impact on vaccinology. Complementing this with an increased understanding of host-virus interactions and the modulation of immune response by viral genes presents us with a promising approach for using recombinant viral vectors, genetically manipulated to change the pattern of the CD8 T cell response. In this regard, CMV presents an ideal viral vector candidate as its lifelong persistence maintains a high number of functional effector CD8 $\mathrm{T}$ cells against vectored antigens without the need for booster doses. We believe that utilizing this virus as a vector can easily find its way to clinical applications against both microbial and neoplastic threats.

Author Contributions: Writing-original draft preparation, M.Š. and M.C.B.; Writing-review and editing, A.K. and S.J. All authors have read and agreed to the published version of the manuscript.

Funding: This publication was supported by Croatian Science Foundation under the project 9086. and by the grant "Strengthening the capacity of CerVirVac for research in virus immunology and vaccinology", KK.01.1.1.01.0006, awarded to the Scientific Centre of Excellence for Virus Immunology and Vaccines and co-financed by the European Regional Development Fund.

Institutional Review Board Statement: Not applicable.

Informed Consent Statement: Not applicable.

Acknowledgments: We thank Luka Traven for critical comments and help.

Conflicts of Interest: The authors declare no conflict of interest.

\section{References}

1. Plotkin, S.A.; Plotkin, S.L. The development of vaccines: How the past led to the future. Nat. Rev. Microbiol. $2011,9,889-893$. [CrossRef] [PubMed]

2. Pollard, A.J.; Bijker, E.M. A guide to vaccinology: From basic principles to new developments. Nat. Rev. Immunol. 2021, 21, 83-100. [CrossRef] [PubMed]

3. Andre, F.E.; Booy, R.; Bock, H.L.; Clemens, J.; Datta, S.K.; John, T.J.; Lee, B.W.; Lolekha, S.; Peltola, H.; Ruff, T.A.; et al. Vaccination greatly reduces disease, disability, death and inequity worldwide. Bull World Health Organ 2008, 86, 140-146. [CrossRef] [PubMed]

4. Orenstein, W.A.; Ahmed, R. Simply put: Vaccination saves lives. Proc. Natl. Acad. Sci. USA 2017, 114, 4031-4033. [CrossRef]

5. Zhou, F.; Shefer, A.; Wenger, J.; Messonnier, M.; Wang, L.Y.; Lopez, A.; Moore, M.; Murphy, T.V.; Cortese, M.; Rodewald, L. Economic Evaluation of the Routine Childhood Immunization Program in the United States, 2009. Pediatrics 2014, 133, 577-585. [CrossRef]

6. Black, R.E.; Morris, S.S.; Bryce, J. Where and why are 10 million children dying every year? Lancet 2003, 361, 2226-2234. [CrossRef]

7. Ozawa, S.; Clark, S.; Portnoy, A.; Grewal, S.; Brenzel, L.; Walker, D.G. Return on Investment from Childhood Immunization in Low- and Middle-Income Countries, 2011-20. Health Aff. 2016, 35, 199-207. [CrossRef]

8. Greenwood, B. The contribution of vaccination to global health: Past, present and future. Philos. Trans. R. Soc. B Biol. Sci. 2014, 369, 20130433. [CrossRef] [PubMed]

9. Plotkin, S.A. Updates on immunologic correlates of vaccine-induced protection. Vaccine 2020, 38, 2250-2257. [CrossRef]

10. Data on the Size of HIV Epidemics. Available online: https://www.who.int/data/gho/data/themes/hiv-aids/data-on-the-sizeof-the-hiv-aids-epidemic (accessed on 4 October 2021).

11. World Malaria Report 2020: 20 Years of Global Progress and Challenges. Available online: https://www.who.int/publications/i/ item/9789240015791 (accessed on 4 October 2021).

12. Global Tuberculosis Report 2020. Available online: https://www.who.int/teams/global-tuberculosis-programme/tb-reports (accessed on 4 October 2021).

13. Gray, G.E.; Laher, F.; Lazarus, E.; Ensoli, B.; Corey, L. Approaches to preventative and therapeutic HIV vaccines. Curr. Opin. Virol. 2016, 17, 104-109. [CrossRef]

14. Beura, L.K.; Jameson, S.C.; Masopust, D. Is a Human CD8 T-Cell Vaccine Possible, and if So, What Would It Take? Cold Spring Harb. Perspect. Biol. 2018, 10, a028910. [CrossRef]

15. Dunn, G.P.; Bruce, A.T.; Ikeda, H.; Old, L.J.; Schreiber, R.D. Cancer immunoediting: From immunosurveillance to tumor escape. Nat. Immunol. 2002, 3, 991-998. [CrossRef] [PubMed] 
16. Chen, D.S.; Mellman, I. Oncology Meets Immunology: The Cancer-Immunity Cycle. Immunity 2013, 39, 1-10. [CrossRef] [PubMed]

17. Chen, D.S.; Mellman, I. Elements of cancer immunity and the cancer-immune set point. Nature 2017, 541, 321-330. [CrossRef]

18. Laidlaw, B.J.; Craft, J.E.; Kaech, S.M. The multifaceted role of CD4 ${ }^{+} \mathrm{T}$ cells in $\mathrm{CD} 8^{+} \mathrm{T}$ cell memory. Nat. Rev. Immunol. 2016, 16, 102-111. [CrossRef]

19. Demers, K.R.; Reuter, M.A.; Betts, M.R. CD8 ${ }^{+}$T-cell effector function and transcriptional regulation during HIV pathogenesis. Immunol. Rev. 2013, 254, 190-206. [CrossRef]

20. Harty, J.T.; Tvinnereim, A.R.; White, D.W. CD8 ${ }^{+}$T cell effector mechanisms in resistance to infection. Annu. Rev. Immunol. 2000, 18, 275-308. [CrossRef]

21. Lehmann-Grube, F.; Moskophidis, D.; Löhler, J. Recovery from acute virus infection. Role of cytotoxic T lymphocytes in the elimination of lymphocytic choriomeningitis virus from spleens of mice. Ann. N. Y. Acad. Sci. 1988, 532, 238-256. [CrossRef]

22. Graham, B.S.; Bunton, L.A.; Wright, P.F.; Karzon, D.T. Role of T lymphocyte subsets in the pathogenesis of primary infection and rechallenge with respiratory syncytial virus in mice. J. Clin. Investig. 1991, 88, 1026-1033. [CrossRef]

23. Moutaftsi, M.; Tscharke, D.C.; Vaughan, K.; Koelle, D.M.; Stern, L.; Calvo-Calle, M.; Ennis, F.; Terajima, M.; Sutter, G.; Crotty, S.; et al. Uncovering the interplay between CD8, CD4 and antibody responses to complex pathogens. Future Microbiol. 2010, 5, 221-239. [CrossRef]

24. Wells, M.A.; Albrecht, P.; Ennis, F.A. Recovery from a viral respiratory infection. I. Influenza pneumonia in normal and T-deficient mice. J. Immunol. 1981, 126, 1036-1041. [PubMed]

25. Bender, B.S.; Croghan, T.; Zhang, L.; Small, P.A. Transgenic mice lacking class I major histocompatibility complex-restricted T cells have delayed viral clearance and increased mortality after influenza virus challenge. J. Exp. Med. 1992, 175, 1143-1145. [CrossRef] [PubMed]

26. Schmitz, J.E. Control of Viremia in Simian Immunodeficiency Virus Infection by CD8+ Lymphocytes. Science 1999, 283, 857-860. [CrossRef] [PubMed]

27. Schmidt, N.W.; Podyminogin, R.L.; Butler, N.S.; Badovinac, V.P.; Tucker, B.J.; Bahjat, K.S.; Lauer, P.; Reyes-Sandoval, A.; Hutchings, C.L.; Moore, A.C.; et al. Memory CD8 T cell responses exceeding a large but definable threshold provide long-term immunity to malaria. Proc. Natl. Acad. Sci. USA 2008, 105, 14017-14022. [CrossRef] [PubMed]

28. Demkowicz, W.E., Jr.; Ennis, F.A. Vaccinia virus-specific CD8+ cytotoxic T lymphocytes in humans. J. Virol. 1993, 67, 1538-1544. [CrossRef]

29. Nanan, R.; Rauch, A.; Kampgen, E.; Niewiesk, S.; Kreth, H.W. A novel sensitive approach for frequency analysis of measles virusspecific memory T-lymphocytes in healthy adults with a childhood history of natural measles. J. Gen. Virol. 2000, 81, 1313-1319. [CrossRef]

30. Akondy, R.S.; Fitch, M.; Edupuganti, S.; Yang, S.; Kissick, H.T.; Li, K.W.; Youngblood, B.A.; Abdelsamed, H.A.; McGuire, D.J.; Cohen, K.W.; et al. Origin and differentiation of human memory CD8 T cells after vaccination. Nature 2017, 552, 362-367. [CrossRef]

31. Sridhar, S.; Begom, S.; Bermingham, A.; Hoschler, K.; Adamson, W.; Carman, W.; Bean, T.; Barclay, W.; Deeks, J.J.; Lalvani, A. Cellular immune correlates of protection against symptomatic pandemic influenza. Nat. Med. 2013, 19, 1305-1312. [CrossRef]

32. Wang, Z.; Wan, Y.; Qiu, C.; Quiñones-Parra, S.; Zhu, Z.; Loh, L.; Tian, D.; Ren, Y.; Hu, Y.; Zhang, X.; et al. Recovery from severe H7N9 disease is associated with diverse response mechanisms dominated by CD8 ${ }^{+}$T cells. Nat. Commun. 2015, 6, 6833. [CrossRef]

33. International HIV Controllers Study. The Major Genetic Determinants of HIV-1 Control Affect HLA Class I Peptide Presentation. Science 2010, 330, 1551-1557. [CrossRef]

34. Migueles, S.A.; Sabbaghian, M.S.; Shupert, W.L.; Bettinotti, M.P.; Marincola, F.M.; Martino, L.; Hallahan, C.W.; Selig, S.M.; Schwartz, D.; Sullivan, J.; et al. HLA B* 5701 is highly associated with restriction of virus replication in a subgroup of HIV-infected long term nonprogressors. Proc. Natl. Acad. Sci. USA 2000, 97, 2709-2714. [CrossRef]

35. Migueles, S.A.; Laborico, A.C.; Shupert, W.L.; Sabbaghian, M.S.; Rabin, R.; Hallahan, C.W.; Baarle, D.V.; Kostense, S.; Miedema, F.; Mclaughlin, M.; et al. HIV-specific $\mathrm{CD}^{+} \mathrm{T}$ cell proliferation is coupled to perforin expression and is maintained in nonprogressors. Nat. Immunol. 2002, 3, 1061-1068. [CrossRef]

36. Migueles, S.A.; Osborne, C.M.; Royce, C.; Compton, A.A.; Joshi, R.P.; Weeks, K.A.; Rood, J.E.; Berkley, A.M.; Sacha, J.B.; CoglianoShutta, N.A.; et al. Lytic granule loading of $\mathrm{CD} 8^{+} \mathrm{T}$ cells is required for HIV-infected cell elimination associated with immune control. Immunity 2008, 29, 1009-1021. [CrossRef]

37. Dahirel, V.; Shekhar, K.; Pereyra, F.; Miura, T.; Artyomov, M.; Talsania, S.; Allen, T.M.; Altfeld, M.; Carrington, M.; Irvine, D.J.; et al. Coordinate linkage of HIV evolution reveals regions of immunological vulnerability. Proc. Natl. Acad. Sci. USA 2011, 108, 11530-11535. [CrossRef]

38. Ferguson, A.L.; Mann, J.K.; Omarjee, S.; Ndung'u, T.; Walker, B.D.; Chakraborty, A.K. Translating HIV sequences into quantitative fitness landscapes predicts viral vulnerabilities for rational immunogen design. Immunity 2013, 38, 606-617. [CrossRef]

39. Barton, J.P.; Goonetilleke, N.; Butler, T.C.; Walker, B.D.; McMichael, A.J.; Chakraborty, A.K. Relative rate and location of intra-host HIV evolution to evade cellular immunity are predictable. Nat. Commun. 2016, 7, 11660. [CrossRef]

40. Pamer, E.G. Immune responses to Listeria monocytogenes. Nat. Rev. Immunol. 2004, 4, 812-823. [CrossRef] [PubMed] 
41. Sullivan, N.J.; Sanchez, A.; Rollin, P.E.; Yang, Z.-Y.; Nabel, G.J. Development of a preventive vaccine for Ebola virus infection in primates. Nature 2000, 408, 605-609. [CrossRef] [PubMed]

42. Sullivan, N.J.; Hensley, L.; Asiedu, C.; Geisbert, T.W.; Stanley, D.; Johnson, J.; Honko, A.; Olinger, G.; Bailey, M.; Geisbert, J.B.; et al. $\mathrm{CD}^{+}$cellular immunity mediates rAd5 vaccine protection against Ebola virus infection of nonhuman primates. Nat. Med. 2011, 17, 1128-1131. [CrossRef]

43. Tipton, T.R.W.; Hall, Y.; Bore, J.A.; White, A.; Sibley, L.S.; Sarfas, C.; Yuki, Y.; Martin, M.; Longet, S.; Mellors, J.; et al. Characterisation of the T-cell response to Ebola virus glycoprotein amongst survivors of the 2013-16 West Africa epidemic. Nat. Commun. 2021, 12, 1-9. [CrossRef] [PubMed]

44. Thimme, R. T cell immunity to hepatitis C virus: Lessons for a prophylactic vaccine. J. Hepatol. 2021, 74, 220-229. [CrossRef] [PubMed]

45. Lechner, F.; Wong, D.K.; Dunbar, P.R.; Chapman, R.; Chung, R.T.; Dohrenwend, P.; Robbins, G.; Phillips, R.; Klenerman, P.; Walker, B.D. Analysis of successful immune responses in persons infected with hepatitis C virus. J. Exp. Med. 2000, 191, 1499-1512. [CrossRef]

46. Kurup, S.P.; Butler, N.S.; Harty, J.T. T cell-mediated immunity to malaria. Nat. Rev. Immunol. 2019, 19, 457-471. [CrossRef] [PubMed]

47. Jasenosky, L.D.; Scriba, T.J.; Hanekom, W.A.; Goldfeld, A.E. T cells and adaptive immunity to Mycobacterium tuberculosisin humans. Immunol. Rev. 2015, 264, 74-87. [CrossRef] [PubMed]

48. Sette, A.; Crotty, S. Adaptive immunity to SARS-CoV-2 and COVID-19. Cell 2021, 184, 861-880. [CrossRef] [PubMed]

49. Doores, K.J. The HIV glycan shield as a target for broadly neutralizing antibodies. FEBS J. 2015, 282, 4679-4691. [CrossRef]

50. Grant, E.J.; Quiñones-Parra, S.M.; Clemens, E.B.; Kedzierska, K. Human influenza viruses and CD8+ T cell responses. Curr. Opin. Virol. 2016, 16, 132-142. [CrossRef]

51. Webster, G.J.M.; Reignat, S.; Brown, D.; Ogg, G.S.; Jones, L.; Seneviratne, S.L.; Williams, R.; Dusheiko, G.; Bertoletti, A. Longitudinal Analysis of CD8 ${ }^{+}$T Cells Specific for Structural and Nonstructural Hepatitis B Virus Proteins in Patients with Chronic Hepatitis B: Implications for Immunotherapy. J. Virol. 2004, 78, 5707-5719. [CrossRef]

52. Le Bert, N.; Tan, A.T.; Kunasegaran, K.; Tham, C.Y.L.; Hafezi, M.; Chia, A.; Chng, M.H.Y.; Lin, M.; Tan, N.; Linster, M.; et al. SARS-CoV-2-specific T cell immunity in cases of COVID-19 and SARS, and uninfected controls. Nature 2020, 584, 457-462. [CrossRef]

53. Oseroff, C.; Kos, F.; Bui, H.-H.; Peters, B.; Pasquetto, V.; Glenn, J.; Palmore, T.; Sidney, J.; Tscharke, D.C.; Bennink, J.R.; et al. HLA class I-restricted responses to vaccinia recognize a broad array of proteins mainly involved in virulence and viral gene regulation. Proc. Natl. Acad. Sci. USA 2005, 102, 13980-13985. [CrossRef]

54. Moutaftsi, M.; Peters, B.; Pasquetto, V.; Tscharke, D.C.; Sidney, J.; Bui, H.-H.; Grey, H.; Sette, A. A consensus epitope prediction approach identifies the breadth of murine $\mathrm{T}_{\mathrm{CD} 8+}$-cell responses to vaccinia virus. Nat. Biotechnol. 2006, 24, 817-819. [CrossRef]

55. Stamper, C.T.; Wilson, P.C. What Are the Primary Limitations in B-Cell Affinity Maturation, and How Much Affinity Maturation Can We Drive with Vaccination? Cold Spring Harb. Perspect. Biol. 2018, 10, a028803. [CrossRef]

56. Yeap, L.-S.; Hwang, J.K.; Du, Z.; Meyers, R.M.; Meng, F.-L.; Jakubauskaite,, A.; Liu, M.; Mani, V.; Neuberg, D.; Kepler, T.B.; et al. Sequence-Intrinsic Mechanisms that Target AID Mutational Outcomes on Antibody Genes. Cell 2015, 163, 1124-1137. [CrossRef]

57. Mesin, L.; Schiepers, A.; Ersching, J.; Barbulescu, A.; Cavazzoni, C.B.; Angelini, A.; Okada, T.; Kurosaki, T.; Victora, G.D. Restricted Clonality and Limited Germinal Center Reentry Characterize Memory B Cell Reactivation by Boosting. Cell 2020, 180, 92-106.e111. [CrossRef]

58. $\quad$ van Gisbergen, K.P.J.M.; Klarenbeek, P.L.; Kragten, N.A.M.; Unger, P.-P.A.; Nieuwenhuis, M.B.B.; Wensveen, F.M.; ten Brinke, A.; Tak, P.P.; Eldering, E.; Nolte, M.A.; et al. The Costimulatory Molecule CD27 Maintains Clonally Diverse CD8 ${ }^{+}$T Cell Responses of Low Antigen Affinity to Protect against Viral Variants. Immunity 2011, 35, 97-108. [CrossRef]

59. Kavazović, I.; Polić, B.; Wensveen, F.M. Cheating the Hunger Games; Mechanisms Controlling Clonal Diversity of CD8 Effector and Memory Populations. Front. Immunol. 2018, 9, 2831. [CrossRef] [PubMed]

60. Kavazović, I.; Han, H.; Balzaretti, G.; Slinger, E.; Lemmermann, N.A.W.; Ten Brinke, A.; Merkler, D.; Koster, J.; Bryceson, Y.T.; De Vries, N.; et al. Eomes broadens the scope of CD8 T-cell memory by inhibiting apoptosis in cells of low affinity. PLoS Biol. 2020, 18, e3000648. [CrossRef] [PubMed]

61. Sallusto, F.; Lenig, D.; Förster, R.; Lipp, M.; Lanzavecchia, A. Two subsets of memory T lymphocytes with distinct homing potentials and effector functions. Nature 1999, 401, 708-712. [CrossRef]

62. Wherry, E.J.; Teichgräber, V.; Becker, T.C.; Masopust, D.; Kaech, S.M.; Antia, R.; Von Andrian, U.H.; Ahmed, R. Lineage relationship and protective immunity of memory CD8 T cell subsets. Nat. Immunol. 2003, 4, 225-234. [CrossRef] [PubMed]

63. Zhou, X.; Yu, S.; Zhao, D.-M.; Harty, J.T.; Badovinac, V.P.; Xue, H.-H. Differentiation and Persistence of Memory CD8 ${ }^{+}$T Cells Depend on T Cell Factor 1. Immunity 2010, 33, 229-240. [CrossRef]

64. Olson, J.A.; Mcdonald-Hyman, C.; Jameson, C.S.; Hamilton, E.S. Effector-like CD8 ${ }^{+}$T Cells in the Memory Population Mediate Potent Protective Immunity. Immunity 2013, 38, 1250-1260. [CrossRef]

65. Martin, M.D.; Badovinac, V.P. Defining Memory CD8 T Cell. Front. Immunol. 2018, 9, 2692. [CrossRef] [PubMed]

66. Banerjee, A.; Gordon, S.M.; Intlekofer, A.M.; Paley, M.A.; Mooney, E.C.; Lindsten, T.; Wherry, E.J.; Reiner, S.L. Cutting edge: The transcription factor eomesodermin enables $\mathrm{CD}^{+} \mathrm{T}$ cells to compete for the memory cell niche. J. Immunol. 2010, 185, 4988-4992. [CrossRef] 
67. Ji, Y.; Pos, Z.; Rao, M.; Klebanoff, C.A.; Yu, Z.; Sukumar, M.; Reger, R.N.; Palmer, D.C.; Borman, Z.A.; Muranski, P.; et al. Repression of the DNA-binding inhibitor Id3 by Blimp-1 limits the formation of memory CD8 ${ }^{+}$T cells. Nat. Immunol. 2011, 12, 1230-1237. [CrossRef]

68. Liu, Z.; Guo, Y.; Tang, S.; Zhou, L.; Huang, C.; Cao, Y.; Huang, H.; Wu, X.; Meng, D.; Ye, L.; et al. Cutting Edge: Transcription Factor BCL6 Is Required for the Generation, but Not Maintenance, of Memory CD8 ${ }^{+}$T Cells in Acute Viral Infection. J. Immunol. 2019, 203, 323-327. [CrossRef]

69. Cui, W.; Liu, Y.; Weinstein, J.S.; Craft, J.; Kaech, S.M. An interleukin-21-interleukin-10-STAT3 pathway is critical for functional maturation of memory CD8 ${ }^{+} \mathrm{T}$ cells. Immunity 2011, 35, 792-805. [CrossRef]

70. Joshi, N.S.; Cui, W.; Chandele, A.; Lee, H.K.; Urso, D.R.; Hagman, J.; Gapin, L.; Kaech, S.M. Inflammation directs memory precursor and short-lived effector $\mathrm{CD}^{+} \mathrm{T}$ cell fates via the graded expression of T-bet transcription factor. Immunity 2007, 27, 281-295. [CrossRef]

71. Rutishauser, R.L.; Martins, G.A.; Kalachikov, S.; Chandele, A.; Parish, I.A.; Meffre, E.; Jacob, J.; Calame, K.; Kaech, S.M. Transcriptional repressor Blimp-1 promotes $\mathrm{CD}^{+} \mathrm{T}$ cell terminal differentiation and represses the acquisition of central memory T cell properties. Immunity 2009, 31, 296-308. [CrossRef]

72. Omilusik, K.D.; Nadjsombati, M.S.; Shaw, L.A.; Yu, B.; Milner, J.J.; Goldrath, A.W. Sustained Id2 regulation of E proteins is required for terminal differentiation of effector CD8 ${ }^{+}$T cells. J. Exp. Med. 2018, 215, 773-783. [CrossRef] [PubMed]

73. Mollo, S.B.; Ingram, J.T.; Kress, R.L.; Zajac, A.J.; Harrington, L.E. Virus-specific CD4 and CD8 T cell responses in the absence of Th1-associated transcription factors. J. Leukoc. Biol. 2014, 95, 705-713. [CrossRef] [PubMed]

74. Milner, J.J.; Nguyen, H.; Omilusik, K.; Reina-Campos, M.; Tsai, M.; Toma, C.; Delpoux, A.; Boland, B.S.; Hedrick, S.M.; Chang, J.T.; et al. Delineation of a molecularly distinct terminally differentiated memory CD8 T cell population. Proc. Natl. Acad. Sci. USA 2020, 117, 25667-25678. [CrossRef] [PubMed]

75. Huster, K.M.; Koffler, M.; Stemberger, C.; Schiemann, M.; Wagner, H.; Busch, D.H. Unidirectional development of CD8 ${ }^{+}$central memory T cells into protectiveListeria-specific effector memory T cells. Eur. J. Immunol. 2006, 36, 1453-1464. [CrossRef]

76. Bachmann, M.F.; Wolint, P.; Schwarz, K.; Jäger, P.; Oxenius, A. Functional Properties and Lineage Relationship of CD8 ${ }^{+}$T Cell Subsets Identified by Expression of IL-7 Receptor $\alpha$ and CD62L. J. Immunol. 2005, 175, 4686-4696. [CrossRef]

77. Klebanoff, C.A.; Gattinoni, L.; Torabi-Parizi, P.; Kerstann, K.; Cardones, A.R.; Finkelstein, S.E.; Palmer, D.C.; Antony, P.A.; Hwang, S.T.; Rosenberg, S.A.; et al. Central memory self/tumor-reactive CD8 ${ }^{+} \mathrm{T}$ cells confer superior antitumor immunity compared with effector memory T cells. Proc. Natl. Acad. Sci. USA 2005, 102, 9571-9576. [CrossRef] [PubMed]

78. Masopust, D.; Soerens, A.G. Tissue-Resident T Cells and Other Resident Leukocytes. Annu. Rev. Immunol. 2019, 37, 521-546. [CrossRef] [PubMed]

79. Mackay, L.K.; Minnich, M.; Kragten, N.A.; Liao, Y.; Nota, B.; Seillet, C.; Zaid, A.; Man, K.; Preston, S.; Freestone, D.; et al. Hobit and Blimp1 instruct a universal transcriptional program of tissue residency in lymphocytes. Science 2016, 352, 459-463. [CrossRef]

80. Milner, J.J.; Toma, C.; Yu, B.; Zhang, K.; Omilusik, K.; Phan, A.T.; Wang, D.; Getzler, A.J.; Nguyen, T.; Crotty, S.; et al. Runx3 programs CD8 ${ }^{+} \mathrm{T}$ cell residency in non-lymphoid tissues and tumours. Nature 2017, 552, 253-257. [CrossRef] [PubMed]

81. Hombrink, P.; Helbig, C.; Backer, R.A.; Piet, B.; Oja, A.E.; Stark, R.; Brasser, G.; Jongejan, A.; Jonkers, R.E.; Nota, B.; et al. Programs for the persistence, vigilance and control of human $\mathrm{CD}^{+}$lung-resident memory T cells. Nat. Immunol. 2016, 17, 1467-1478. [CrossRef]

82. Behr, F.M.; Kragten, N.A.M.; Wesselink, T.H.; Nota, B.; van Lier, R.A.W.; Amsen, D.; Stark, R.; Hombrink, P.; van Gisbergen, K. Blimp-1 Rather Than Hobit Drives the Formation of Tissue-Resident Memory CD8 ${ }^{+}$T Cells in the Lungs. Front. Immunol. 2019, 10, 400. [CrossRef]

83. Wijeyesinghe, S.; Beura, L.K.; Pierson, M.J.; Stolley, J.M.; Adam, O.A.; Ruscher, R.; Steinert, E.M.; Rosato, P.C.; Vezys, V.; Masopust, D. Expansible residence decentralizes immune homeostasis. Nature 2021, 592, 457-462. [CrossRef]

84. Masopust, D. Preferential Localization of Effector Memory Cells in Nonlymphoid Tissue. Science 2001, 291, 2413-2417. [CrossRef] [PubMed]

85. Masopust, D.; Vezys, V.; Wherry, E.J.; Barber, D.L.; Ahmed, R. Cutting Edge: Gut Microenvironment Promotes Differentiation of a Unique Memory CD8 T Cell Population. J. Immunol. 2006, 176, 2079-2083. [CrossRef]

86. Schenkel, J.M.; Fraser, K.A.; Vezys, V.; Masopust, D. Sensing and alarm function of resident memory CD8 ${ }^{+}$T cells. Nat. Immunol. 2013, 14, 509-513. [CrossRef]

87. Milner, J.J.; Toma, C.; He, Z.; Kurd, N.S.; Nguyen, Q.P.; McDonald, B.; Quezada, L.; Widjaja, C.E.; Witherden, D.A.; Crowl, J.T.; et al. Heterogenous Populations of Tissue-Resident CD8. Immunity 2020, 52, 808-824. [CrossRef] [PubMed]

88. Gebhardt, T.; Wakim, L.M.; Eidsmo, L.; Reading, P.C.; Heath, W.R.; Carbone, F.R. Memory T cells in nonlymphoid tissue that provide enhanced local immunity during infection with herpes simplex virus. Nat. Immunol. 2009, 10, 524-530. [CrossRef] [PubMed]

89. Schenkel, J.M.; Fraser, K.A.; Beura, L.K.; Pauken, K.E.; Vezys, V.; Masopust, D. Resident memory CD8 T cells trigger protective innate and adaptive immune responses. Science 2014, 346, 98-101. [CrossRef] [PubMed]

90. Stary, G.; Olive, A.; Radovic-Moreno, A.F.; Gondek, D.; Alvarez, D.; Basto, P.A.; Perro, M.; Vrbanac, V.D.; Tager, A.M.; Shi, J.; et al. A mucosal vaccine against Chlamydia trachomatis generates two waves of protective memory T cells. Science 2015, 348 , aaa8205. [CrossRef] 
91. Shin, H.; Iwasaki, A. A vaccine strategy that protects against genital herpes by establishing local memory T cells. Nature 2012, 491, 463-467. [CrossRef]

92. Schenkel, J.M.; Masopust, D. Tissue-Resident Memory T Cells. Immunity 2014, 41, 886-897. [CrossRef]

93. Jiang, X.; Clark, R.A.; Liu, L.; Wagers, A.J.; Fuhlbrigge, R.C.; Kupper, T.S. Skin infection generates non-migratory memory CD8 ${ }^{+}$ TRM cells providing global skin immunity. Nature 2012, 483, 227-231. [CrossRef]

94. Malik, B.T.; Byrne, K.T.; Vella, J.L.; Zhang, P.; Shabaneh, T.B.; Steinberg, S.M.; Molodtsov, A.K.; Bowers, J.S.; Angeles, C.V.; Paulos, C.M.; et al. Resident memory T cells in the skin mediate durable immunity to melanoma. Sci. Immunol. 2017, 2, eaam6346. [CrossRef] [PubMed]

95. Park, S.L.; Buzzai, A.; Rautela, J.; Hor, J.L.; Hochheiser, K.; Effern, M.; Mcbain, N.; Wagner, T.; Edwards, J.; Mcconville, R.; et al. Tissue-resident memory CD8+ T cells promote melanoma-immune equilibrium in skin. Nature 2019, 565, 366-371. [CrossRef]

96. Savas, P.; Virassamy, B.; Ye, C.; Salim, A.; Mintoff, C.P.; Caramia, F.; Salgado, R.; Byrne, D.J.; Teo, Z.L.; Dushyanthen, S.; et al. Single-cell profiling of breast cancer T cells reveals a tissue-resident memory subset associated with improved prognosis. Nat. Med. 2018, 24, 986-993. [CrossRef] [PubMed]

97. Djenidi, F.; Adam, J.; Goubar, A.; Durgeau, A.; Meurice, G.; De Montpréville, V.; Validire, P.; Besse, B.; Mami-Chouaib, F. $\mathrm{CD}^{+} \mathrm{CD}_{103}{ }^{+}$Tumor-Infiltrating Lymphocytes Are Tumor-Specific Tissue-Resident Memory T Cells and a Prognostic Factor for Survival in Lung Cancer Patients. J. Immunol. 2015, 194, 3475-3486. [CrossRef]

98. Webb, J.R.; Milne, K.; Watson, P.; Deleeuw, R.J.; Nelson, B.H. Tumor-infiltrating lymphocytes expressing the tissue resident memory marker CD103 are associated with increased survival in high-grade serous ovarian cancer. Clin. Cancer Res. 2014, 20, 434-444. [CrossRef]

99. Park, S.L.; Gebhardt, T.; Mackay, L.K. Tissue-Resident Memory T Cells in Cancer Immunosurveillance. Trends Immunol. 2019, 40, 735-747. [CrossRef]

100. Enamorado, M.; Iborra, S.; Priego, E.; Cueto, F.J.; Quintana, J.A.; Martínez-Cano, S.; Mejías-Pérez, E.; Esteban, M.; Melero, I.; Hidalgo, A.; et al. Enhanced anti-tumour immunity requires the interplay between resident and circulating memory CD8. Nat. Commun. 2017, 8, 16073. [CrossRef]

101. Liu, L.; Zhong, Q.; Tian, T.; Dubin, K.; Athale, S.K.; Kupper, T.S. Epidermal injury and infection during poxvirus immunization is crucial for the generation of highly protective T cell-mediated immunity. Nat. Med. 2010, 16, 224-227. [CrossRef]

102. Sandoval, F.; Terme, M.; Nizard, M.; Badoual, C.; Bureau, M.-F.; Freyburger, L.; Clement, O.; Marcheteau, E.; Gey, A.; Fraisse, G.; et al. Mucosal Imprinting of Vaccine-Induced CD8 ${ }^{+}$T Cells Is Crucial to Inhibit the Growth of Mucosal Tumors. Sci. Transl. Med. 2013, 5, 172ra120. [CrossRef]

103. Nizard, M.; Roussel, H.; Diniz, M.O.; Karaki, S.; Tran, T.; Voron, T.; Dransart, E.; Sandoval, F.; Riquet, M.; Rance, B.; et al. Induction of resident memory $\mathrm{T}$ cells enhances the efficacy of cancer vaccine. Nat. Commun. 2017, 8, 15221. [CrossRef]

104. Iwasaki, A. Exploiting Mucosal Immunity for Antiviral Vaccines. Annu. Rev. Immunol. 2016, 34, 575-608. [CrossRef]

105. Klenerman, P.; Oxenius, A. T cell responses to cytomegalovirus. Nat. Rev. Immunol. 2016, 16, 367-377. [CrossRef] [PubMed]

106. Wallace, D.L.; Masters, J.E.; De Lara, C.M.; Henson, S.M.; Worth, A.; Zhang, Y.; Kumar, S.R.; Beverley, P.C.; Akbar, A.N.; Macallan, D.C. Human cytomegalovirus-specific CD8 ${ }^{+}$T-cell expansions contain long-lived cells that retain functional capacity in both young and elderly subjects. Immunology 2011, 132, 27-38. [CrossRef] [PubMed]

107. Komatsu, H.; Sierro, S.A.V.C.; Klenerman, P. Population analysis of antiviral T cell responses using MHC class I-peptide tetramers. Clin. Exp. Immunol. 2003, 134, 9-12. [CrossRef] [PubMed]

108. Hansen, S.G.; Vieville, C.; Whizin, N.; Coyne-Johnson, L.; Siess, D.C.; Drummond, D.D.; Legasse, A.W.; Axthelm, M.K.; Oswald, K.; Trubey, C.M.; et al. Effector memory T cell responses are associated with protection of rhesus monkeys from mucosal simian immunodeficiency virus challenge. Nat. Med. 2009, 15, 293-299. [CrossRef] [PubMed]

109. Hansen, S.G.; Ford, J.C.; Lewis, M.S.; Ventura, A.B.; Hughes, C.M.; Coyne-Johnson, L.; Whizin, N.; Oswald, K.; Shoemaker, R.; Swanson, T.; et al. Profound early control of highly pathogenic SIV by an effector memory T-cell vaccine. Nature 2011, 473, 523-527. [CrossRef] [PubMed]

110. Hansen, S.G.; Piatak, M., Jr.; Ventura, A.B.; Hughes, C.M.; Gilbride, R.M.; Ford, J.C.; Oswald, K.; Shoemaker, R.; Li, Y.; Lewis, M.S.; et al. Immune clearance of highly pathogenic SIV infection. Nature 2013, 502, 100-104. [CrossRef]

111. Hansen, S.G.; Sacha, J.B.; Hughes, C.M.; Ford, J.C.; Burwitz, B.J.; Scholz, I.; Gilbride, R.M.; Lewis, M.S.; Gilliam, A.N.; Ventura, A.B.; et al. Cytomegalovirus Vectors Violate CD8+ T Cell Epitope Recognition Paradigms. Science 2013, 340, 1237874. [CrossRef]

112. Hansen, S.G.; Wu, H.L.; Burwitz, B.J.; Hughes, C.M.; Hammond, K.B.; Ventura, A.B.; Reed, J.S.; Gilbride, R.M.; Ainslie, E.; Morrow, D.W.; et al. Broadly targeted $\mathrm{CD}^{+} \mathrm{T}$ cell responses restricted by major histocompatibility complex E. Science 2016, 351, 714-720. [CrossRef]

113. Verweij, M.; Hansen, S.G.; Iyer, R.; John, N.; Malouli, D.; Morrow, D.; Scholz, I.; Womack, J.; Abdulhaqq, S.; Gilbride, R.M.; et al. Modulation of MHC-E transport by viral decoy ligands is required for RhCMV/SIV vaccine efficacy. Science 2021, 372 , eabe9233. [CrossRef]

114. Hansen, S.G.; Zak, D.E.; Xu, G.; Ford, J.C.; Marshall, E.E.; Malouli, D.; Gilbride, R.M.; Hughes, C.M.; Ventura, A.B.; Ainslie, E.; et al. Prevention of tuberculosis in rhesus macaques by a cytomegalovirus-based vaccine. Nat. Med. 2018, 24, 130-143. [CrossRef] 
115. Hansen, S.G.; Womack, J.; Scholz, I.; Renner, A.; Edgel, K.A.; Xu, G.; Ford, J.C.; Grey, M.; St. Laurent, B.; Turner, J.M.; et al. Cytomegalovirus vectors expressing Plasmodium knowlesi antigens induce immune responses that delay parasitemia upon sporozoite challenge. PLoS ONE 2019, 14, e0210252. [CrossRef]

116. Geraghty, D.E.; Stockschleader, M.; Ishitani, A.; Hansen, J.A. Polymorphism at the HLA-E locus predates most HLA-A and -B polymorphism. Hum. Immunol. 1992, 33, 174-184. [CrossRef]

117. Grimsley, C.; Ober, C. Population genetic studies of HLA-E: Evidence for selection. Hum. Immunol. 1997, 52, 33-40. [CrossRef]

118. VIR-1111: A Prototype Human CMV-Based Vaccine for Human Immunodeficiency Virus (HIV) in Healthy Volunteers. Available online: https:/ / clinicaltrials.gov/ct2/show / NCT04725877 (accessed on 4 October 2021).

119. Zheng, X.; Oduro, J.D.; Boehme, J.D.; Borkner, L.; Ebensen, T.; Heise, U.; Gereke, M.; Pils, M.C.; Krmpotic, A.; Guzman, C.A.; et al. Mucosal CD8 ${ }^{+} \mathrm{T}$ cell responses induced by an MCMV based vaccine vector confer protection against influenza challenge. PLoS Pathog. 2019, 15, e1008036. [CrossRef]

120. Tsuda, Y.; Caposio, P.; Parkins, C.J.; Botto, S.; Messaoudi, I.; Cicin-Sain, L.; Feldmann, H.; Jarvis, M.A. A Replicating Cytomegalovirus-Based Vaccine Encoding a Single Ebola Virus Nucleoprotein CTL Epitope Confers Protection against Ebola Virus. PLoS Negl. Trop. Dis. 2011, 5, e1275. [CrossRef] [PubMed]

121. Marzi, A.; Murphy, A.A.; Feldmann, F.; Parkins, C.J.; Haddock, E.; Hanley, P.W.; Emery, M.J.; Engelmann, F.; Messaoudi, I.; Feldmann, H.; et al. Cytomegalovirus-based vaccine expressing Ebola virus glycoprotein protects nonhuman primates from Ebola virus infection. Sci. Rep. 2016, 6, 21674. [CrossRef] [PubMed]

122. Beyranvand Nejad, E.; Ratts, R.B.; Panagioti, E.; Meyer, C.; Oduro, J.D.; Cicin-Sain, L.; Fruh, K.; van der Burg, S.H.; Arens, R. Demarcated thresholds of tumor-specific CD8 T cells elicited by MCMV-based vaccine vectors provide robust correlates of protection. J. Immunother. Cancer 2019, 7, 25. [CrossRef]

123. Erkes, D.A.; Xu, G.; Daskalakis, C.; Zurbach, K.A.; Wilski, N.A.; Moghbeli, T.; Hill, A.B.; Snyder, C.M. Intratumoral Infection with Murine Cytomegalovirus Synergizes with PD-L1 Blockade to Clear Melanoma Lesions and Induce Long-term Immunity. Mol. Ther. 2016, 24, 1444-1455. [CrossRef]

124. Benonisson, H.; Sow, H.S.; Breukel, C.; Claassens, J.W.C.; Brouwers, C.; Linssen, M.M.; Redeker, A.; Fransen, M.F.; van Hall, T.; Ossendorp, F.; et al. FcgammaRI expression on macrophages is required for antibody-mediated tumor protection by cytomegalovirus-based vaccines. Oncotarget 2018, 9, 29392-29402. [CrossRef]

125. Klyushnenkova, E.N.; Kouiavskaia, D.V.; Parkins, C.J.; Caposio, P.; Botto, S.; Alexander, R.B.; Jarvis, M.A. A cytomegalovirusbased vaccine expressing a single tumor-specific $\mathrm{CD} 8^{+} \mathrm{T}$-cell epitope delays tumor growth in a murine model of prostate cancer. J. Immunother. 2012, 35, 390-399. [CrossRef]

126. Wensveen, F.M.; Jelenčić, V.; Polić, B. NKG2D: A Master Regulator of Immune Cell Responsiveness. Front. Immunol. 2018, 9 , 441. [CrossRef] [PubMed]

127. Slavuljica, I.; Busche, A.; Babić, M.; Mitrović, M.; Gašparović, I.; Cekinović, Đ.; Markova Car, E.; Pernjak Pugel, E.; Ciković, A.; Lisnić, V.J.; et al. Recombinant mouse cytomegalovirus expressing a ligand for the NKG2D receptor is attenuated and has improved vaccine properties. J. Clin. Investig. 2010, 120, 4532-4545. [CrossRef] [PubMed]

128. Trsan, T.; Busche, A.; Abram, M.; Wensveen, F.M.; Lemmermann, N.A.; Arapovic, M.; Babic, M.; Tomic, A.; Golemac, M.; Brinkmann, M.M.; et al. Superior induction and maintenance of protective CD8 T cells in mice infected with mouse cytomegalovirus vector expressing RAE-1. Proc. Natl. Acad. Sci. USA 2013, 110, 16550-16555. [CrossRef] [PubMed]

129. Tršan, T.; Vuković, K.; Filipović, P.; Brizić, A.L.; Lemmermann, N.A.W.; Schober, K.; Busch, D.H.; Britt, W.J.; Messerle, M.; Krmpotić, A.; et al. Cytomegalovirus vector expressing RAE-1 $\gamma$ induces enhanced anti-tumor capacity of murine CD8 ${ }^{+} \mathrm{T}$ cells. Eur. J. Immunol. 2017, 47, 1354-1367. [CrossRef]

130. Zhao, X.; Shan, Q.; Xue, H.-H. TCF1 in T cell immunity: A broadened frontier. Nat. Rev. Immunol. 2021. [CrossRef] [PubMed]

131. Šustić, M.; Cokarić Brdovčak, M.; Lisnić, B.; Materljan, J.; Juranić Lisnić, V.; Rožmanić, C.; Indenbirken, D.; Hiršl, L.; Busch, D.H.; Brizić, I.; et al. Memory CD8 T Cells Generated by Cytomegalovirus Vaccine Vector Expressing NKG2D Ligand Have Effector-Like Phenotype and Distinct Functional Features. Front. Immunol. 2021, 12, 2035. [CrossRef] [PubMed]

132. Hiršl, L.; Brizić, I.; Jenuš, T.; Juranić Lisnić, V.; Reichel, J.J.; Jurković, S.; Krmpotić, A.; Jonjić, S. Murine CMV Expressing the High Affinity NKG2D Ligand MULT-1: A Model for the Development of Cytomegalovirus-Based Vaccines. Front. Immunol. 2018, 9, 991. [CrossRef]

133. Tomić, A.; Varanasi, P.R.; Golemac, M.; Malić, S.; Riese, P.; Borst, E.M.; Mischak-Weissinger, E.; Guzmán, C.A.; Krmpotić, A.; Jonjić, S.; et al. Activation of Innate and Adaptive Immunity by a Recombinant Human Cytomegalovirus Strain Expressing an NKG2D Ligand. PLoS Pathog. 2016, 12, e1006015. [CrossRef]

134. Hansen, S.G.; Powers, C.J.; Richards, R.; Ventura, A.B.; Ford, J.C.; Siess, D.; Axthelm, M.K.; Nelson, J.A.; Jarvis, M.A.; Picker, L.J.; et al. Evasion of CD8 ${ }^{+}$T Cells Is Critical for Superinfection by Cytomegalovirus. Science 2010, 328, 102-106. [CrossRef] 